\title{
Fifth Amendment Limitations on the Use of Police Testimony to Rebut the Insanity Defense
}

\author{
Andrew J. Ferren $\dagger$
}

John Hinckley, Jr.'s acquittal by reason of insanity for the attempted assassination of President Reagan outraged many observers. Crucial to the success of Hinckley's insanity plea was the trial court's exclusion of "demeanor" testimony offered by two FBI agents who had unlawfully interrogated Hinckley without the presence of the attorney he had requested. ${ }^{2}$ The D.C. Circuit affirmed the exclusion of that evidence on Fifth Amendment grounds. ${ }^{3}$ Specifically, the court rejected the government's arguments for a waiver of Fifth Amendment protection and, alternatively, for a new insanity rebuttal exception to the exclusionary rule enunciated in Miranda $v$ Arizona. ${ }^{4}$

Six years later, the Eleventh Circuit refused to apply Hinckley when it upheld the admission of police demeanor testimony in Jones $v$ Dugger. ${ }^{5}$ The court held that the prosecution could present a police detective's opinion testimony to rebut Jones's insanity defense, despite Miranda violations, where the detective never revealed Jones's specific statements and gave no indication that his opinion was based on the substance of Jones's story. ${ }^{6}$ Even though five expert witnesses agreed that Jones suffered from serious mental illness, ${ }^{7}$ the jury apparently relied on the officer's lay

\footnotetext{
† A.B. 1986, Harvard University; J.D. Candidate 1991, The University of Chicago.

1 Judicial opinions typically do not define demeanor evidence. This Comment treats demeanor as any bodily evidence other than verbal statements used for their content. Demeanor therefore includes the manner in which a suspect speaks as well as non-verbal aspects of his voluntary or involuntary behavior and appearance. See text at notes 84-86.

2 United States v Hinckley, 529 F Supp 520, 522 (D DC 1982) (Amended Statement of Reasons), clarifying 525 F Supp 1342 (D DC 1981).

s United States v Hinckley, 672 F2d 115 (DC Cir 1982).

484 US 436 (1966).

s 839 F2d 1441 (11th Cir 1988).

- Id at 1444.

? Id at 1453 (Clark dissenting).
} 
opinion, as well as the presumption of sanity, ${ }^{8}$ in deciding to convict Jones. ${ }^{9}$

This Comment explores the extent to which a law enforcement officer should be permitted to testify about a defendant's sanity when his knowledge stems from observations of the defendant's demeanor made during a custodial interrogation lacking required procedural safeguards. Two kinds of testimony are at issue: opinions about the defendant's sanity and observations of the defendant's demeanor. Even if a police witness were prevented from stating his opinion about the defendant's sanity, timely police observations could corroborate, or serve as a basis for, later expert diagnoses. ${ }^{10}$ Such testimony, based on observations at or immediately after the time of the alleged crime, may be considerably more persuasive than expert medical opinion testimony based on belated observations. ${ }^{11}$

Before considering the admissibility of police testimony, this Comment discusses the scope of the Fifth Amendment exclusionary rule. Section I lays out the current doctrinal approach to the admissibility of evidence under the Fifth Amendment's self-incrimination clause. Section II discusses the contrasting applications of these principles by the courts in Hinckley and Jones. The Comment identifies four theories the prosecution might advance in response to a defense motion to suppress police testimony offered to prove sanity. Initially, the prosecution could argue that the Fifth Amendment does not apply because either (1) no evidence of sanity is "incriminating," or (2) the police testimony at issue involves only "real," not "testimonial," evidence. Alternatively, the prosecution could argue that even if the evidence is both incriminating and testimonial, (3) the defendant waived Fifth Amendment protection by pleading and attempting to prove insanity, or (4) the evidence should be admitted under a new insanity rebuttal exception to the Fifth Amendment exclusionary rule.

\footnotetext{
8 In all jurisdictions a defendant is presumed sane until he places his sanity in issue. See Michael L. Perlin, 3 Mental Disability Law § 15.12 at 320 (Michie, 1989).

- See Jones, 839 F2d at 1453 (Clark dissenting).

10 See Welsh S. White, The Psychiatric Examination and the Fifth Amendment Privilege in Capital Cases, $74 \mathrm{~J}$ Crim L \& Criminol 943, 944 n 5 (1983), citing cases admitting such derivative opinions. See also FRE 703. In many jurisdictions, an expert may not state an opinion as to sanity where sanity is an element of the crime or of a defense, but may explain why he believes the defendant was or was not able to appreciate the wrongfulness of his conduct. See, for example, FRE 704(b).

11 See Richard M. Daley and Inge Fryklund, The Insanity Defense and the "Testimony By Proxy" Problem, 21 Valp U L Rev 497, 501 (1987); Edward B. Beis, Mental Health and the Law 280 (Aspen, 1984).
} 
Section III considers the applicability of the Fifth Amendment to police-obtained evidence of sanity. It argues that all evidence of sanity is incriminating, and that demeanor evidence of sanity is testimonial when obtained by virtue of the officer's psychiatric expertise. Section IV rejects the arguments that either a waiver exception or an insanity rebuttal exception to the exclusionary rule can be applied to this type of evidence.

The Comment thus extends the testimonial evidence test to the insanity defense context and concludes that courts should bar all police-compelled evidence that is testimonial. Under the proposed standard, police officers may not state their opinions concerning the defendant's sanity, but courts may permit lay officers to relate observations of the defendant's nontestimonial demeanor. Expert officers would be prevented from testifying even about the defendant's demeanor because their observation method violates the privilege against self-incrimination.

\section{The Scope of the Fifth Amendment Exclusionary Rule}

In Miranda, the Supreme Court announced the Fifth Amendment exclusionary rule: statements obtained during custodial interrogation absent prescribed warnings and a valid waiver (or equally effective procedural safeguards) are constitutionally inadmissible at trial. ${ }^{12}$ This rule derives from the command that "[n]o person ... shall be compelled in any criminal case to be a witness against himself." 13 Thus, unlike its judicially created Fourth Amendment counterpart, ${ }^{14}$ the Fifth Amendment exclusionary rule is constitutionally mandated: "[t]he Fifth Amendment . . is by its terms an exclusionary rule . ..."

The constitutional text does not further explain the scope of this privilege against self-incrimination. Miranda clarified that the privilege attaches not only at trials but during pre-trial custodial

12384 US at $444,476$.

${ }^{23}$ US Const, Amend V. The privilege against self-incrimination applies to state as well as federal proceedings. Malloy $v$ Hogan, 378 US 1, 8 (1964); Berkemer v McCarty, 468 US 420,428 (1984). Similarly, the exclusionary rule applies to the states. Mapp v Ohio, 367 US 643,655 (1961).

${ }^{14}$ The Fourth Amendment protects persons against unreasonable searches and seizures, thereby securing privacy and property rights. The corresponding exclusionary rule was first enunciated in Weeks $v$ United States, 232 US 383, 398 (1914), and its judicially created status has been reaffirmed in Stone v Powell, 428 US 465, 482, 486 (1976).

${ }^{16}$ United States v Kurzer, 534 F2d 511, 516 (2d Cir 1976). See also Arnold H. Loewy, Police-Obtained Evidence and the Constitution: Distinguishing Unconstitutionally $O b$ tained Evidence from Unconstitutionally Used Evidence, 87 Mich L Rev 907, 926 (1989). 
interrogations as well..$^{16}$ Yet, other applications of the self-incrimination clause remain controversial. This Section sets forth the relevant prerequisites and exceptions to the exclusionary rule.

\section{A. Prerequisites to the Exclusionary Rule}

Three prerequisites must coincide before a pre-trial custodial interrogation triggers the Fifth Amendment exclusionary rule. A defendant who moves to suppress evidence allegedly obtained in violation of his privilege must establish that it was compelled, incriminating, and testimonial. ${ }^{17}$ Because this Comment posits a custodial interrogation in which the defendant's responses are "compelled,"18 it explores only the "incrimination" and "testimonial" requirements.

1. "Incrimination": Smith's extension of Miranda to capital sentencing.

"Incriminating" evidence is not limited to evidence that establishes factual guilt. In Estelle $v$ Smith, ${ }^{19}$ for example, the Court extended the Fifth Amendment exclusionary rule to statements the prosecution obtained during a custodial psychiatric examination and then sought to use at a murder trial's sentencing phase. The Court explained that the availability of the privilege against self-incrimination depends not on the type of proceeding, but on the nature of the evidence and the exposure it invites. ${ }^{20}$

Leaving open the possibility that a defendant might waive the privilege by claiming insanity, the Smith Court concluded that "[a] criminal defendant, who neither initiates a psychiatric evaluation nor attempts to introduce any psychiatric evidence, may not be compelled to respond to a psychiatrist if his statements can be used against him at a capital sentencing proceeding." ${ }^{21}$ The jury's finding of dangerousness warranting death was as serious as its finding of guilt because Smith's dangerousness dictated the sever-

\footnotetext{
16 384 US at 461, citing Bram v United States, 168 US 532, 542 (1897).

17 See, for example, Baltimore City Dept. of Social Services v Bouknight, $110 \mathrm{~S}$ Ct 900 , 904 (1990).

18 In the usual custodial interrogation, compulsion is presumed in the absence of $M i$ randa warnings.

19451 US 454 (1981).

${ }^{20}$ Id at 462, quoting In re Gault, 387 US 1, 49 (1967) (privilege may be invoked in juvenile delinquency proceeding with potential commitment to reform school).

21 Id at 468.
} 
ity of his punishment. The Fifth Amendment's protection against self-incrimination therefore applied.

2. "Testimonial": Schmerber's distinction between "real" and "testimonial" evidence.

Although one could read the self-incrimination clause literally to cover any incriminating evidence supplied by a suspect, courts have traditionally construed it more narrowly. The Court's 5-4 decision in Schmerber $v$ California ${ }^{22}$ confirmed that certain physical evidence is not subject to the Fifth Amendment exclusionary rule. While the state may not compel a suspect to testify against himself or otherwise provide testimonial or communicative evidence, the state may force him to supply "real or physical evidence."23

In Schmerber, the Court upheld the use of a compelled blood test in a prosecution for drunk driving. Justice Brennan's majority opinion conceded that a suspect may refuse not only to testify but also to provide the state with testimonial evidence, ${ }^{24}$ which may include communicative responses in the form of acts or words. ${ }^{25}$ The Court also indicated in dictum that some tests (such as lie detector tests) that attempt to discover the suspect's knowledge of guilt by measuring his physiological responses to questioning implicate the Fifth Amendment. ${ }^{28}$ But compelled submission to the gathering of physical evidence would not involve the suspect's communicative capacities in any way. Schmerber's forcibly extracted blood, though incriminating, was not testimonial evidence because his mental participation was irrelevant to the test results. $^{27}$

\section{B. Exceptions to the Exclusionary Rule}

Even if compelled, incriminating, and testimonial, some illegally obtained evidence may be admissible under either of two exceptions to the exclusionary rule. ${ }^{28}$ First, some courts have adopted

22384 US 757 (1966).

${ }^{23}$ Id at 764.

24 Id at 761.

${ }^{25}$ Id at $761 \mathrm{n} 5$ (acknowledging that a nod or head-shake may be as testimonial or communicative as spoken words). See also id at 763 .

28 Id at 764 .

37 Id at 765 .

${ }^{28}$ Other exceptions include using tainted evidence to locate a witness, Michigan $v$ Tucker, 417 US 433,450 (1974), and using it as the basis for questioning in a grand jury proceeding when the witness is granted use immunity, United States v Calandra, 414 US 328, 346, 351-52 (1974). In neither case is the evidence used directly to convict a suspect. 
a "waiver by offer of psychiatric evidence" doctrine, ${ }^{2 \theta}$ in which a defendant who pleads and attempts to prove insanity must consent to the prosecution's compulsion and use of expert psychiatric testimony in rebuttal. These courts have sidestepped Smith and the issues of whether psychiatric testimony is really incriminating and testimonial by holding that, once a defendant offers expert evidence in support of an insanity defense, he opens the door to expert rebuttal evidence, even if the prosecution obtained that evidence in violation of Miranda. ${ }^{30}$ Proponents of this "waiver by offer of psychiatric evidence" doctrine argue that the fairness concerns of the adversarial system burden the right to present psychiatric testimony, and that the opportunity to cross-examine the defendant's expert witnesses does not sufficiently honor these fairness concerns. ${ }^{31}$

A second, more general exception to the exclusionary rule is the impeachment exception. A statement inadmissible against the defendant in the prosecution's case-in-chief because of a Miranda violation may be used to impeach the testifying defendant's credibility if the statement satisfies legal standards of trustworthiness. ${ }^{32}$ Absent evidence of compulsion, ${ }^{33}$ the Fourth Amendment test of balancing the public interest in truth at trial against the individual interest in privacy applies in the Fifth Amendment context. ${ }^{34}$ When combined with a testimony-by-proxy theory, ${ }^{36}$ the impeach-

20 White, $74 \mathrm{~J}$ Crim L \& Criminol at 950 (cited in note 10 ).

so See, for example, Isley $v$ Dugger, 877 F2d 47, $49-50$ (11th Cir 1989); Granviel $v$ Lynaugh, 881 F2d 185, 190 (5th Cir 1989), cert denied 110 S Ct 2577 (1990); United States $v$ Madrid, 673 F2d 1114, 1120-21 (10th Cir 1982); People v Gacy, 125 Ill 2d 117, 530 NE2d 1340, 1351 (1988); and People v Poggi, 45 Cal 3d 306, 753 P2d 1082, 1097 (1988). This theory is analogous to the testimonial waiver doctrine in the law of evidence, under which a defendant who testifies in court opens himself to cross-examination within the scope of his direct testimony.

s1 White, $74 \mathrm{~J}$ Crim L \& Criminol at 956 (cited in note 10).

s2 Harris $v$ New York, 401 US 222, 224 (1971), relying on Walder $v$ United States, 347 US 62, 65 (1954) (defendant's direct testimony opened door for prosecution to impeach defendant with evidence obtained in violation of the Fourth Amendment).

ss The impeachment exception is unavailable only when the defendant can show compulsion affirmatively, beyond the presumption created by custody and interrogation alone. See Mincey v Arizona, 437 US 385, 398-402 (1978).

s4 See also Oregon $v$ Hass, 420 US 714, 722 (1975) (extending Harris to case in which defendant was told his rights and requested lawyer, but police questioning continued in violation of Miranda); United States v Havens, 446 US 620 (1980) (allowing prosecutors to use illegally obtained evidence to impeach statements defendant made for the first time on cross-examination).

ss The testimony-by-proxy theory posits that the defendant's expert witness takes the stand and relates the defendant's statements, some of which may concern the defendant's version of the crime, as foundation for the expert's opinion. 
ment exception might support a narrow insanity rebuttal exception to the exclusionary rule.

\section{Contrasting Applications of the Exclusionary Rule}

Two federal appellate courts have dealt directly with the questions addressed in this Comment. Although the cases are technically reconcilable, they send mixed signals about the admissibility of police testimony to rebut an insanity defense. They also indicate the complexity and importance of this issue..$^{36}$

\section{A. Hinckley}

FBI agents interrogated Hinckley before his requested attorney arrived. ${ }^{37}$ The district court granted Hinckley's motion to suppress his statements and the fruits thereof. ${ }^{38}$ Later, the court issued a statement explaining that its earlier ruling also precluded "any demeanor testimony by the agents concerning the manner in which Hinckley responded to their questions, as well as their perception of his responses."39 The jury subsequently acquitted Hinckley by reason of insanity.

On appeal to the D.C. Circuit, the government contended that even if the evidence from the interrogation was obtained unconstitutionally, the court nevertheless should admit it for the limited purpose of rebutting the insanity defense. First, the government argued that Smith permits the prosecution to compel a defendant who has put his sanity in issue to submit to a psychiatric exam. The court, however, distinguished the psychiatric exam with its attendant safeguards from the general use of illegally obtained lay testimony to rebut insanity. ${ }^{40}$ And while conceding certain other exceptions to the exclusionary rule, the court rejected the government's waiver argument. The court maintained that the deterrence

\footnotetext{
38 Hinckley and Jones are discussed in detail in Note, The Admissibility of Mental State Observations Obtained During Unlawful Custodial Interrogation: Drawing the Line on the Real or Physical Evidence Distinction, 30 BC L Rev 1029, 1047-58 (1989), which argues that Jones was wrongly decided because all mental state observations, as a unitary group, categorically belong to the testimonial evidence class. The author analyzes "mental status" evidence, not "demeanor" evidence, which might be considered a subset of the former category. In addition, the author focuses only on the distinction between real and testimonial evidence, and does not distinguish evidence obtained by law enforcement officers from evidence obtained by psychiatrists and other mental health experts.

37672 F2d at $119-21$.

ss 525 F Supp at 1351, 1358.

38 $529 \mathrm{~F}$ Supp at 522 .

672 F2d at 133 n 116.
} 
rationale remains important whenever government agents can anticipate both the use of an insanity defense and the concurrent role of demeanor evidence. ${ }^{41}$

Second, the government offered the testimony-by-proxy theory to support an insanity rebuttal exception to the exclusionary rule. The court dismissed this theory on the ground that insanity is indistinguishable from other affirmative defenses to which the rebuttal theory would not apply. ${ }^{42}$ Thus, the court rejected both the proposed extension of the waiver doctrine and the proposed insanity rebuttal exception to the exclusionary rule.

\section{B. Jones}

Over two hours after a police detective began interrogating Jones in custody, Jones cried and confessed to robbery, kidnapping, and sexual battery. When he was finally found competent at his third pretrial competency hearing, Jones moved to suppress his statements on the ground that he had not intelligently waived his Miranda rights. The trial court excluded the statements but, over Jones's objection, allowed the police detective to state both his observations of Jones's demeanor and his opinion that Jones was sane. Following conviction, affirmance, ${ }^{43}$ and habeas corpus denial, the case reached the Eleventh Circuit Court of Appeals.

The Eleventh Circuit majority decided that the Schmerber real evidence distinction controlled Jones's case. The detective never related any specific statements made by Jones and, in particular, never stated that Jones confessed to the crimes. In addition, he gave no indication that his opinion of Jones's sanity was based on the details of Jones's statements. "None of these observations related to the substance of Jones' story," the court concluded. "[T]hey were more like demeanor evidence, observations that Jones was alert and comprehending." itive proof that the detective's opinion did not in fact rest on the details of Jones's remarks, the majority believed that a defendant's statements and demeanor could be separated in determining their admissibility.

41 Id at $133 \& \mathrm{n} 117$. Thus, the court accepted the idea that the deterrence rationale applies to the Fifth as well as the Fourth Amendment. Contrast Loewy, 87 Mich L Rev at 926-28 (cited in note 15).

12672 F2d at 134.

43 Jones $v$ State, 465 S2d 1330 (Fla App 1985).

$4839 \mathrm{~F} 2 \mathrm{~d}$ at 1445 . 
In dissent, Judge Clark dismissed the majority's analogy to the real evidence admitted in Schmerber, and argued that Smith and related decisions invalidated any attempt to parse the detective's testimony so as to render him a source of real evidence. ${ }^{45}$ Clark found it inconceivable that the detective did not base his testimony on Jones's communicative acts. ${ }^{46}$ The judge also opined that a communication need not relate the substance of what the declarant has said in order to be testimonial. Rather, the testimonial threshold was satisfied because the interrogator's questions to the defendant were diagnostic; they enabled the interrogator to measure and evaluate the defendant's physical and oral responses. ${ }^{47}$

Judge Clark also based his conclusion on the detective's status as a lay observer. The views of an observer without psychiatric training, he argued, necessarily depend largely on what the suspect says, especially when the purpose of the interview is to discover the crime's details. ${ }^{48}$ Here, Clark argued, the detective was not the "detached, clinical observer" the majority portrayed him to be. But neither Judge Clark nor the majority addressed the admissibility of lay or expert police testimony relating only discrete observations of sane behavior and appearance without stating conclusory opinions.

* * * *

While the Hinckley court was preoccupied with criticizing the government's proposed waiver and insanity rebuttal exceptions to the Fifth Amendment exclusionary rule, the Jones majority reached only the real/testimonial evidence distinction. Demeanor evidence might have been admitted in Hinckley if the government had not also insisted on introducing Hinckley's statements. Similarly, if there had been any substantive support for Judge Clark's assumption that the detective's opinions rested on Jones's statements, then the Jones majority's real/testimonial distinction would have been difficult to make. ${ }^{49}$ But even if Hinckley and Jones can technically be reconciled, the two cases together confuse the scope of admissible police testimony concerning a defendant's sanity.

45 Id at 1446 (Clark dissenting).

16 Id at 1447 (Clark dissenting).

47 Id at 1448 (Clark dissenting).

48 Id at 1449-50 (Clark dissenting).

49 Another important factual distinction between Hinckley and Jones may have been the relative expertise of the interrogators. See text at notes 87-92. 


\section{Police-obtained Sanity Evidence And the FifTh AMENDMENT}

Consistent with the self-incrimination jurisprudence outlined above, police testimony offered to prove sanity might be admissible under several theories. Such evidence could be admissible if it fails to implicate the Fifth Amendment, on the ground that it is either not "incriminating" or not "testimonial." Or, even if the evidence is both incriminating and testimonial, it might be admitted under either a waiver theory or a new insanity rebuttal exception to the Fifth Amendment exclusionary rule.

The remainder of this Comment addresses these theories in turn. Some police testimony offered to prove sanity implicates the Fifth Amendment because all such evidence is incriminating and some of it is testimonial. After this Section offers a standard to determine when such evidence is testimonial, Section IV of the Comment rejects application of either the waiver theory or the insanity rebuttal exception in exclusionary rule analysis for police testimony.

\section{A. The Incriminating Character of Sanity Evidence}

Some courts have avoided the complex inquiry into whether particular evidence of sanity is testimonial by holding that evidence of sanity is never incriminating within the meaning of the Fifth Amendment. ${ }^{50}$ Others have maintained that the defendant can raise the privilege against self-incrimination to exclude sanity evidence. ${ }^{1}$ The better view treats sanity evidence as incriminating because it affects a defendant's ultimate disposition. ${ }^{62}$

Smith implies that courts should consider sanity evidence incriminating as long as it affects the severity or quality of the defendant's punishment. In reasoning that a post-guilt determination of dangerousness warranted continued Fifth Amendment protection, the Smith Court relied on In re Gault, which had emphasized that the scope of the privilege depends on the defendant's poten-

so See, for example, DeVine $v$ Solem, 815 F2d 1205, 1207 (8th Cir 1987); People v Nelson, 92 Ill App 3d 35, 415 NE2d 688, 693 (1980), and cases cited therein.

51 See, for example, Walker v Butterworth, 599 F2d 1074, 1084 (1st Cir 1979); People v Flores, 55 Cal App 3d 118, 127 Cal Rptr 230, 232 (1976).

s2 The Supreme Court has yet to resolve the lower courts' division on this issue. Somewhat surprisingly, Hinckley, Jones, and many other decisions ignore the incrimination prerequisite to the exclusionary rule and rely on other grounds. Numerous courts apparently have assumed, without deciding, that sanity evidence is incriminating. See, for example, Brown v Butler, 876 F2d 427, 429-30 (5th Cir 1989). 
tial exposure. ${ }^{53}$ The Gault Court disregarded the civil label on a juvenile delinquency proceeding because a determination of delinquency would result in commitment to a state institution. Whether labeled civil or criminal, such a commitment results in a deprivation of liberty. ${ }^{54}$ Similarly, a defendant who is found sane faces prison (or even death), a more severe deprivation of liberty than the hospitalization that awaits the insane defendant..$^{55}$

A minority of courts have stated that evidence of sanity is incriminating. In United States $v$ Byers, for example, then-Judge Scalia stated in a plurality opinion of the D.C. Circuit sitting en banc that rebutting the insanity defense to obtain a conviction is like finding the dangerousness necessary to impose the death penalty. ${ }^{56}$ Dissenting on other grounds, Judge Bazelon asserted that if sanity is a condition of criminal liability, then sanity evidence is incriminating whether it arises at the determination of guilt or sanction. ${ }^{.7}$

Many decisions holding that sanity evidence is not incriminating offer little analysis, but one may glean four rebuttable arguments for this position from the cases. First, a prosecutor might argue that "incriminate" literally means "to show guilt," in the sense that the defendant actually did the criminal act with which he is charged..$^{88}$ Such a construction would exclude sanity. But the Constitution does not use the word "incriminate," which is simply

ss Smith, 451 US at 462, citing Gault, 387 US at 49.

34 Gault, 387 US at 50. Despite Gault, most courts hold that sanity is not incriminating in the context of involuntary civil commitment. See, for example, In re Bobo, 376 NW2d 429, 433-34 (Minn App 1985); People v Keith, $38 \mathrm{Ill}$ 2d 405, 231 NE2d 387, 390 (1967). Courts disagree on whether denial or revocation of parole or probation implicates the Fifth Amendment. Contrast Williams v Turner, 702 F Supp 1439, 1448 (W D Mo 1988), aff'd as Lombardo v United States, 865 F2d 155 (7th Cir 1989) (implicated), with State v Sites, 231 Neb 624, 437 NW2d 166, 168 (1989) (not implicated).

ss In Wainwright v Greenfield, 474 US 284, 295 (1986), the Supreme Court held that use of a defendant's post-arrest, post-Miranda silence as evidence of his sanity violated the due process clause of the Fourteenth Amendment. This holding expanded the application of Doyle $v$ Ohio, 426 US 610 (1976), in which the use of post-Miranda silence as evidence of guilt was held to violate the implicit assurance contained in the Miranda warnings that silence carries no penalty. If the Court was willing to extend the Doyle principle to the sanity phase of a trial, it should be willing similarly to extend the Smith principle.

so 740 F2d 1104, 1113 (DC Cir 1984) (en banc) (plurality opinion).

s7 Id at 1150 (Bazelon dissenting). The North Carolina Supreme Court recently followed the Byers interpretation of Smith, rejecting "non-incrimination" as a basis for admitting sanity evidence because that theory was "implicitly rejected in Smith." State v Huff, $325 \mathrm{NC} 1,381 \mathrm{SE} 2 \mathrm{~d} 635,660 \mathrm{n} 9$ (1989), cert granted and judgment as to sentencing vacated and remanded on other gounds, $110 \mathrm{~S} \mathrm{Ct} 3266$ (1990).

ss In Counselman v Hitchcock, the Court explained that the privilege against self-incrimination was intended to cover testimony that shows that the declarant had "committed a crime." 142 US 547, 562 (1892). 
a judicial label for the privilege. Being a witness against oneself, therefore, could readily include any action that goes to one's criminal culpability.

Second, the prosecution might argue that sanity evidence does not prove guilt (including mens rea) in those jurisdictions where it is not an element of the crime. And evidence that does not show guilt does not contribute to conviction. ${ }^{59}$ This distinction between the state's initial burden of proving its case and a later finding of sanity seems unpersuasive in light of Smith, however. Smith's death sentence was based on a finding of future dangerousness, which was not an element of guilt. If the Court was willing to extend Fifth Amendment protection to sentencing, it should not matter whether sanity is an element of the crime. After all, few would argue that because self-defense, like insanity, is an affirmative defense, the defendant's statement "I knew the victim would not attack" is not incriminating.

A third, related argument is that, unlike the dangerousness issue in Smith, sanity does not help the state punish but merely determines the moral basis for imposing punishment. Only after such a determination can the court decide the actual penalty. ${ }^{60}$ This argument is transparent because, regardless of the stage at which sanity becomes an issue, sanity does determine punishment. Delaying the sentencing decision until after a determination of the defendant's sanity does not change the reality that insane persons generally go to hospitals, but sane persons go to prison-or are executed.

Finally, the prosecutor might argue that because the defendant's liberty will be restricted either in a hospital or in a prison, excluding the evidence of sanity does not harm the defendant, and thus, in this context, the court may disregard the privilege. ${ }^{61}$ This argument completely ignores qualitative differences in incarceration. ${ }^{62}$ Hospitalization almost certainly is less harmful to the insane acquittee when the alternative for the sane convict is capital

\footnotetext{
so See, for example, White $v$ United States, 451 A2d 848, 852 (DC App 1982); People $v$ Baker, 210 Cal App 3d 681, 258 Cal Rptr 621, 633 (1989) (observing that the state shoulders its burden to prove its case without the defendant's help before reaching the sanity issue), vacated and transferred for reconsideration on other grounds, 262 Cal Rptr 385 (Cal 1989).

Bo White, $451 \mathrm{~A} 2 \mathrm{~d}$ at 853.

61 See Note, Requiring a Criminal Defendant to Submit to a Government Psychiatric Examination: An Invasion of the Privilege Against Self-Incrimination, 83 Harv L Rev 648, 665 (1970).

${ }^{82}$ In addition, it ignores the trend in the Supreme Court's reasoning reflected in Greenfield, 474 US at 295 . See note 55.
} 
punishment or life imprisonment with no possibility of parole. As the insanity defense is more likely to be raised when a defendant faces such dire consequences, this comparison should be quite persuasive in many cases.

But the comparative harm rationale also applies where the incremental harm from a finding of sanity is smaller. For example, crucial evidence that increases an offense from manslaughter to murder surely qualifies as incriminating. In such a case, the number of years in jail would be increased. No prosecutor would argue that evidence producing this result is not incriminating because the defendant would be convicted of at least the lesser included crime and would be imprisoned on that basis alone. Likewise, evidence that rebuts an insanity defense and exposes the defendant to harmful prison conditions should be deemed incriminating. An insane person will probably receive less severe punishment in a hospital than does a convicted person in a prison. Hospital confinement may be shorter, and the inmate, in addition to receiving the necessary medical attention, may find the hospital environment more pleasant. ${ }^{63}$ Furthermore, if the self-incrimination clause is viewed as a trial right, the prosecutor's argument mistakenly collapses the possible outcomes. Evidence of sanity leads to conviction and away from a not guilty by reason of insanity finding or from complete acquittal and hence must be seen as incriminating.

\section{B. A Testimonial Standard for Police-obtained Sanity Evidence}

Once a court concludes that sanity evidence is incriminating, it must decide whether the particular police testimony at issue is based on testimonial evidence. This discussion first presents the prevailing testimonial evidence test and its rationale. Next, it offers a way to extend this test to police-obtained evidence of sanity. The Comment concludes that evidence should be considered testimonial whenever the government interrogator uses expertise to extract from the suspect's mind information that tends to show his sanity. Demeanor evidence is thus testimonial when acquired by a police officer with psychological expertise.

As applied to various types of police testimony, this test requires that courts prevent expert officers from stating not only their opinions about the defendant's mental state, but also any un-

os Report of the Governor's Commission to Revise the Mental Health Code of Illinois 69 (May 8, 1989). Prison inmates may find it easier to obtain temporary release or parole, however. Id at 70. See also Note, 83 Harv L Rev at 665 (cited in note 61). 
derlying observations. However, courts should allow lay officers to relate discrete observations of nontestimonial demeanor. Because even modest expertise will likely violate a suspect's Fifth Amendment rights, courts should adopt a rebuttable presumption of sufficient expertise.

1. The prevailing testimonial evidence standard.

The Supreme Court has developed a testimonial evidence analysis that turns on whether the suspect's statement or conduct explicitly or implicitly asserts some fact, belief, or other information in the suspect's mind. ${ }^{64}$ In Doe $v$ United States, a majority of the Court stated that "in order to be testimonial, an accused's communication must itself, explicitly or implicitly, relate a factual assertion or disclose information." the dissent's view that the accused must not be forced to disclose his mind's contents. ${ }^{66}$ More recently, Pennsylvania $v$ Muniz reaffirmed the Doe definition, ${ }^{67}$ and five Justices attempted to refine its core meaning: "Whenever a suspect is asked for a response requiring him to communicate an express or implied assertion of fact or belief, the suspect confronts the 'trilemma' of truth, falsity, or

64 Without attempting to resolve the ongoing debate over the true purposes of the selfincrimination clause, see Yale Kamisar, Wayne R. LaFave, and Jerold H. Israel, Modern Criminal Procedure 697-702 (West, 7th ed 1990), this Comment proceeds from the view that mental privacy is a core value underlying the privilege against self-incrimination. See, for example, Peter Arenella, Schmerber and the Privilege Against Self-Incrimination: A Reappraisal, 20 Am Crim L Rev 31, 41-42 (1982). The classic litany of the values underlying the Fifth Amendment exclusionary rule appeared in Murphy $v$ Waterfront Commission, 378 US 52,55 (1964) (for example, the desire to maintain a fair state-individual balance by requiring the state to shoulder the entire burden, and respect for individual privacy and the inviolability of the human personality), but no consensus has emerged favoring any particular value over the others. One problem with the Murphy framework is that it seems to assume that only statements can be testimonial, whereas Schmerber confirmed two years later that assertive actions such as a nod or head-shake also could fit that category. 384 US at $761 \mathrm{n} 5$.

Like courts, commentators disagree about the test that should be used to distinguish between real and testimonial evidence. Compare Arenella, $20 \mathrm{Am}$ Crim L Rev at 39, 43 (construing Schmerber as establishing single assertive conduct test), with Note, $30 \mathrm{BC}$ L Rev at 1036, 1059 (cited in note 36) (construing Schmerber as establishing alternative'purpose-based and substance-based tests). See also Charles G. Geyh, The Testimonial Component of the Right Against Self-Incrimination, 36 Cath U L Rev 611, 637 (1987); B. Michael Dann, The Fifth Amendment Privilege Against Self-Incrimination: Extorting Physical Evidence From A Suspect, 43 S Cal L Rev 597, 611, 626-27 (1970).

${ }^{63} 487$ US 201, 210 (1988).

${ }^{68}$ Id at 210-11 \& n 9, citing Couch v United States, 409 US 322, 328 (1973) (extortion of information from accused), and Curcio $v$ United States, 354 US 118, 128 (1957) (attempt to force disclosure of mind's contents implicates the self-incrimination clause).

${ }^{67} 110$ S Ct 2638, 2646-47 (1990). 
silence and hence the response (whether based on truth or falsity) contains a testimonial component."

Under this test, simple distinctions between statements and conduct are unhelpful. A survey of well-settled examples of real and testimonial evidence demonstrates that statements are not necessarily testimonial and that nonverbal conduct may be as testimonial as an oral confession. ${ }^{69}$ Suspects supply real evidence when they give a voice ${ }^{70}$ or handwriting ${ }^{71}$ exemplar. Their ability to talk or write is a foregone conclusion, ${ }^{72}$ and the statement extracts no assertion from the suspect's mind-the content of the words is not probative of guilt. Conversely, the act of producing subpoenaed documents may be testimonial when it reveals the suspect's knowledge of their existence, location, or authenticity. ${ }^{33}$

2. Extending the standard to evidence of mens rea and sanity.

The prevailing test does not readily translate to evidence of mens rea and sanity. Because the Court has not applied the testimonial evidence test to these issues, its primary worry has been that the government will invade a suspect's mind to extract information concerning his factual guilt, not his mens rea or sanity. ${ }^{74}$ Testimonial evidence has been limited to a suspect's verbal or nonverbal assertions about the crime. Under this narrow view of the test, sanity evidence presumably would be testimonial only when it reflects the defendant's knowledge of his sanity at the time he committed the crime.

But where interrogation extracts from the suspect's mind communicative processes relevant to mental state or sanity, such evidence should be considered testimonial regardless of whether it is an affirmative assertion. The Court's emphasis on protecting mental privacy suggests that the key issue is not whether evidence constitutes an affirmative assertion, but whether it is extracted

es Id at 2648.

68 Schmerber, 384 US at 761 n 5; Muniz, $110 \mathrm{~S} \mathrm{Ct}$ at $2647 \mathrm{n} 9$.

70 United States v Dionisio, 410 US 1, 5-7 (1973).

7 Gilbert v California, 388 US 263, 266-67 (1967).

${ }^{2}$ In contrast, sanity is in dispute once the defendant produces some evidence to rebut the sanity presumption.

73 See United States v Doe, 465 US 605 (1984). Compare Doe v United States, 487 US 201, 219 (1988) (compelling subject of grand jury investigation to authorize foreign banks to disclose records of his accounts, without identifying those documents or acknowledging their existence, does not violate subject's privilege).

${ }^{74}$ See People v Hager, 69 NY2d 141, 505 NE2d 237, 238 (1987) (per curiam); Brooks v 'nited States, 494 A2d 922, 924 (DC App 1984). 
from the suspect's mind. Under this broader view of the test, demeanor evidence of sanity would be testimonial not only when it reflects the defendant's knowledge of his sanity, but whenever it reveals the contents of his mind. Courts should deem evidence testimonial whenever a government interrogator uses expertise to extract information from the suspect's mind that is probative of his actus reus, mens rea, or sanity, even though that evidence, if perceived by a lay observer, would fit the ordinary class of real demeanor evidence. Both the historical roots of the real evidence category and the lower courts' approaches to interrogation scenarios analogous to Hinckley and Jones lend weight to this view of the testimonial test.

a) Historical roots of the real evidence category. According to one commentator, the real evidence category developed in response to advancing forensic science and a concomitant need to obtain valuable physical evidence from the defendant's body without violating the Fifth Amendment. ${ }^{25}$ The prosecution would use this evidence to prove that the defendant was the person who committed the crime, rather than to assess the mental state with which he committed it. The state has traditionally used demeanor evidence to prove actus reus. When used in that way, such evidence does not implicate the contents of the suspect's mind at all.

But when used to prove sanity, demeanor evidence reveals the mind's contents. This probing of the mind's contents evokes the testimonial element of Fifth Amendment analysis. The failure to recognize physiological evidence of mental condition as testimonial in at least some interrogation scenarios would expand the real evidence "exception" beyond its original purpose. A suspect faces a "cruel trilemma"76 when he does not know how to behave, much less speak, in the face of expert interrogation.

b) Analogous custodial interrogation scenarios. The lower courts' approaches to polygraph evidence and psychiatric examination evidence support this broad view of the testimonial standard. In each of these contexts, expert investigators analyze physical responses to questioning as an indirect means of asking the suspect to reveal his mind's contents. ${ }^{77}$ The resulting evidence is used to

${ }^{78}$ Geyh, 36 Cath U L Rev at 626, 634 (cited in note 64).

${ }^{78}$ See Murphy, 378 US at 55.

${ }^{77}$ A third analogy is the compelled sobriety test. Unlike polygraph and psychiatric tests, sobriety tests administered by expert interrogators produce real demeanor evidence. In Muniz, for example, the Court found the manner in which a defendant speaks to be real evidence. $110 \mathrm{~S} \mathrm{Ct} 2638$ (1990). But intoxication must be distinguished from sanity and 
determine guilt. Lower courts classify this evidence as testimonial, even though it includes no affirmative assertions by the suspect about the alleged crime.

Polygraph tests generate testimonial evidence when the interrogator gathers evidence of the suspect's pulse, perspiration, respiration, and other involuntary physiological symptoms of lying. Even though the interrogator bypasses the suspect's affirmative participation, the test violates the Fifth Amendment's protection against forced probing of the mind by measuring physiological responses to questioning. Lower courts uniformly classify the results of lie detector tests as testimonial. ${ }^{78}$

Psychological tests requiring vocal responses and active cooperation generate testimonial evidence because they compel the defendant to communicate his mental status. The compelled psychiatric examination probes a suspect's mind for evidence of mental condition by analyzing his verbal and physiological responses to questioning. Lower courts have thus classified such evidence as testimonial. ${ }^{79}$ It is crucial to recognize that the psychiatric exam uses not only the contents of statements but also simultaneous demeanor evidence to assess sanity. ${ }^{80}$ In Gholson $v$ Estelle, the Fifth

mental status-driving while intoxicated is a strict liability offense that depends only on the suspect's actus reus. See, for example, Ill Rev Stat ch 951/2, § 11-501(a)(1) (1989); People v Thorson, 145 Ill App 3d 764, 496 NE2d 304, 306 (1986) (interpreting statute). Thus, physical evidence of intoxication alone does not implicate mental privacy. Muniz itself distinguished between real evidence of the manner of speech and testimonial evidence of the suspect's response when asked the date of his sixth birthday. Only the latter is testimonial because it forced Muniz to communicate his mental impairment. $110 \mathrm{~S} \mathrm{Ct}$ at 2646. Although the prosecution did not care about the correct answer, the answer's confused content constituted a testimonial assertion from which drunkenness could be inferred. Id at 2649.

${ }^{78}$ See, for example, Garmon v Lumpkin County, Ga., 878 F2d 1406, 1410 (11th Cir 1989); People v Daniels, 422 NYS2d 832, 842, 102 Misc 2d 540 (S Ct 1979). Truth serum similarly has been rejected. See, for example, State v Allies, 186 Mont 99, 606 P2d 1043, 1051-52 (1979).

79 Before Smith, some courts thought psychiatric exams developed only real evidence. See, for example, People v Nelson, 92 Ill App 3d 35, 415 NE2d 688, 693 (1980). But Smith held that when the substance of the defendant's statements (including his silence) affected the psychiatrist's diagnosis, the resulting testimony revealed testimonial evidence. 451 US at 464,465 . See also Byers, 740 F2d at 1112 (stating that Smith categorically rejected idea that psychiatric exams do not gather testimonial evidence); Note, 83 Harv L Rev at 652-60 (cited in note 61) (psychiatric exams gather testimonial evidence because they determine the subject's ideas, thought patterns, and attitudes).

${ }^{\text {so }}$ As one article on psychiatric evaluations explained,

In a pre-arraignment psychiatric examination it is not just "what you say," the content of communication, that may be used against you. It is how you say it, the emotions you display, the way they fit or fail to fit with what you say, the degree of logicality of your thinking, the relationship between your patterns of thought and other data, and even what you don't say that affect the psychiatrist's report. These are all aspects of the process of your communication, and are far more fundamental to the psychiatric exam than the simplistic "what you say." 
Circuit held that physiological reactions elicited by psychiatrists are testimonial. ${ }^{81}$

The psychiatric examination analogy suggests that a suspect's demeanor as well as statement contents would result in testimonial evidence if elicited by a police officer with psychiatric expertise. Such expertise enables the officer to extract mental status information from the suspect by analyzing his responses to interrogation.

3. Applying the standard to police testimony about sanity.

The variety of possible testimony on the issue of sanity complicates the application of the testimonial evidence test. For example, a police officer might offer his opinion that the defendant was sane and then testify to the defendant's demeanor, statements, or both. Alternatively, the officer might relate only discrete observations underlying a tacit opinion. Those observations could include the defendant's statements, or they might be limited to his demeanor. Finally, particular demeanor evidence might be real or testimonial.

As a general matter, opinions must be distinguished from the observations that support them. The line between opinions and underlying observations may be as difficult to draw as the line separating testimonial and real evidence. For example, the observation that the suspect seemed or acted "normal" or "rational" approaches an opinion that the suspect was sane. In contrast, the observation that the suspect was "quiet" or "calm" may lack the more conclusory connotation of testimony concerning normalcy. Courts might identify opinions by asking whether any expertise was involved in making the observation and whether the police of-

Randolph A. Read, Can a "Psychiatric Miranda" Work? A California Perspective, 14 Rutgers L J 431, 435-36 (1983) (emphasis in original). See also Schneider v Lynaugh, 835 F2d 570, 573 (5th Cir 1988) (psychiatrist indicated that in determining sanity he considered five categories: general physical appearance and behavior; manner of speaking; facial expressions reflecting emotional state; ability to express thoughts; and orientation as to time, place, and person).

${ }^{81} 675$ F2d 734, 739-40 (5th Cir 1982). The Gholson court left open the possibility that conclusions based only on a defendant's facial expressions or other physical behavior might sustain the physical evidence analogy. Id at 740-41. But an absence of compulsion, express or implied, would render the testimonial inquiry unnecessary and would fall outside the police interrogation scenario in Hinckley and Jones. Moreover, an expert cannot reach an opinion without comparing statement contents to abstract demeanor. Donald W. Goodwin and Samuel B. Guze, Psychiatric Diagnosis 301-08 (Oxford, 4th ed 1989) (to analyze mental status, psychiatrist should examine appearance and behavior, form and content of thought, affect and mood, memory and intellectual functioning, and insight and judgment). 
ficer was expressing some conclusion as opposed to mere support for an unstated opinion. ${ }^{82}$

A court clearly would not admit an opinion based on compelled, testimonial evidence under the Fifth Amendment exclusionary rule. An opinion based solely on real evidence, in contrast, would survive Fifth Amendment scrutiny, and a court would subject it only to the law of evidence. As the Court reasoned in Smith and as Judge Clark reasoned in Jones, a judge would have to exclude an opinion based on both real and testimonial evidence compelled from the suspect. ${ }^{83}$ Of course, the inadmissibility of an opinion would not automatically render the underlying observations inadmissible. The two-tier hierarchy requires that the court determine the admissibility of any opinion testimony only after analyzing the admissibility of discrete observations that underlie the opinion.

Evidence that could form the basis for a conclusion about the defendant's sanity may be subdivided into several categories: (1) verbal statements used for the truth of their substance (e.g., "I was sane when I shot the victim."); (2) verbal statements used for their substance regardless of truth (e.g., "I wield Satan's power."); (3) manner of verbalizations (e.g., slurred, rapid, loud); (4) voluntary, assertive behavior (e.g., facial expressions, nodding, pointing, crying); and (5) involuntary, nonassertive behavior (e.g., sweating, blushing, sneezing). A possible sixth category could include the absence of the foregoing types of conduct, namely silence and/or stillness. ${ }^{84}$ Categories one and two indisputably constitute testimonial evidence, while categories three through six are varieties of demeanor evidence ${ }^{85}$ that are more difficult to classify as real or testimonial. ${ }^{88}$

82 See also FRE 701 (use of opinion by lay witness limited to those rationally based on his perception and helpful to understanding of testimony).

ss Unlike a partially invalid search warrant which may be "redacted" so that evidence obtained pursuant to valid, severable portions of the warrant need not be suppressed (see United States v Christine, 687 F2d 749, 758 (3d Cir 1982)), evidence of a defendant's statements and nontestimonial demeanor obtained in violation of Miranda cannot be so easily parsed.

st The Fourteenth Amendment would often prohibit use of this evidence. Wainwright $v$ Greenfield, 474 US 284, 295 (1986). See note 55.

ss The Supreme Court has never explicitly defined demeanor as a body of evidence, and it would seem impossible to treat demeanor evidence as a unitary class. Nevertheless, courts appear to use "demeanor" to mean any manifestations of physical or emotional behavior other than the content of oral statements. See note 1.

so There is also a category of real evidence that is not demeanor: aspects of the body that reflect no conduct by the suspect, such as blood, a tattoo, a scar, or a crooked nose. 
Consistent with the testimonial standard developed above, courts should classify categories three through six as testimonial based on the expertise of the interrogator: evidence is testimonial if the interrogator extracts it from the defendant's mind through his psychiatric expertise. A piece of evidence is testimonial not by its nature alone, but also by the context of its'acquisition.

a) Interrogator expertise as a means of classifying testimony. A police officer lacking psychiatric expertise, such as the detective in Jones, is unable to engage in the type of diagnostic probing done by a psychiatrist. The suspect accordingly needs less Fifth Amendment protection with respect to his physiological responses to questioning, but as much if not more protection with respect to the substance of his verbal responses. This is because the police officer must rely mainly on the suspect's statements in forming an opinion about the suspect's sanity. ${ }^{87}$ The court would have to exclude the officer's opinion because the statement's substance-which is concededly testimonial regardless of truth $^{88}$ - would be the primary basis for that opinion. Thus, courts should limit police officers without psychiatric expertise to relating discrete observations of the suspect's demeanor underlying their tacit opinions. ${ }^{89}$ This demeanor evidence could include both involuntary, nonassertive behavior and the manner of the suspect's speech (i.e., everything short of statement contents and voluntary, assertive behavior).

As Hinckley shows, however, some law enforcement officers may have considerable psychiatric expertise. FBI agents, unlike typical police officers, are highly trained to prevent and investigate assassination attempts on major political figures. ${ }^{90}$ Such agents are acutely aware of the importance of their testimony about a suspect's demeanor, and can also anticipate that suspects they arrest may have mental problems. ${ }^{91}$ With expert officers, as with a government psychiatrist, the state's coercive power takes on a new di-

Unlike the previous six categories, the suspect does not produce this type of evidence in response to interrogation or other stimulus.

${ }^{87}$ Jones, 839 F2d at 1449-50 (Clark dissenting).

${ }^{88}$ See Muniz, $110 \mathrm{~S}$ Ct at 2646.

89 Courts disagree on the evidentiary standards for admissibility of lay sanity opinions. Contrast Commonwealth v Monico, 396 Mass 793, 488 NE2d 1168, 1175 (1986) (inadmissible), with Denham v State, 574 SW2d 129, 131 (Tex Crim App 1978) (en banc) (admissible). The Michigan Supreme Court has held that lay sanity opinions are competent even to rebut expert opinions. People v Murphy, 416 Mich 453, 331 NW2d 152, 157-58 (1982). Of course, constitutional requirements trump evidentiary considerations.

9o Hinckley, 672 F2d at 133.

91 Id at 133-34. 
mension. Unlike the average officer whose coercive powers can uncover only evidence of actus reus and specific intent, the expert officer may be able to compel communicative sanity evidence from the suspect. ${ }^{82}$.

If the interrogator makes the suspect speak (even without using questions about the crime's details) in order to judge the coherence of the suspect, testimonial evidence would result. If the interrogator's questions caused the suspect to squirm, sweat, or make other involuntary responses, those responses too would be testimonial, similar to the physiological responses to a polygraph test. Thus, any observations made by an expert officer should be considered testimonial and should be excluded as violative of the Fifth Amendment. And since the court cannot admit the expert officer's observations in such a case, it likewise should exclude his opinions based upon them.

b) Assessing officer expertise. Once courts understand the importance of an officer's expertise in classifying his testimony regarding sanity, they need a method to assess that expertise in a given case. Expertise may be gauged in terms of two requirements: ability and opportunity. ${ }^{93}$ Police officers in most jurisdictions have received only brief mental health training. ${ }^{94}$ But studies indicate that the state can fairly easily train officers "to recognize psychopathology and to report it accurately."95 Therefore, most police officers will likely possess some training and experience with unstable persons, ${ }^{96}$ and, if they have such expertise, they will almost certainly use it. This is not to say that the typical police officer's

92 Of course, any officer might provoke the same reactions, but only the expert officer would notice and understand their significance. Furthermore, the expert officer's questions might be geared to the discovery of sanity evidence.

93 Under the law of evidence, expertise is generally ascertained by assessing the witness's qualifications, such as knowledge, skill, experience, training, and education. See FRE 702.

"4 Craig Fisher, ed, Police Ill-Equipped to Handle the Mentally Ill, Study Finds, 17 Crim Justice Newsletter 5 (May, 1986) (police recruits average only 4.3 hours of mental health training).

"s Samuel S. Janus, et al, Training Police Officers to Distinguish Mental Illness, 137 Am J Psychiatry 228, 229 (1980) (officers who received 16 hours of lectures, case material, and films significantly outscored control group in describing subjects' appearance, behavior, speech, and other characteristics). See also Marc Levinson and M. K. Distefano, Jr., Effects of Brief Training on Mental Health Knowledge and Attitudes of Law Enforcement Officers, 7 J Police Sci \& Admin 241, 242, 244 (1979) (13 hours of classroom training, two hours of testing, and one-hour tour of mental hospital improved knowledge and attitudes to the level of mental hospital attendants).

96 Ninety-four percent of officers in one survey reported contact with mentally ill people. See id at 241 . 
ability to diagnose sanity or insanity will equal that of a forensic psychiatrist. Frequent contact with mentally ill people does not mean that officers can classify a person who is on the margin between insanity and a lesser form of mental illness. One commentator has noted that even an expert psychiatrist needs at least two hour-long interviews involving multiple tests to develop sufficient data for an evaluation.97

But the typical officer will have enough expertise to jeopardize a suspect's privilege against self-incrimination. For example, certain screening questions can help non-psychiatrists decide quickly the relative abnormality of a suspect's mental state. ${ }^{98}$ Furthermore, lay persons with just minimal training can administer some standardized structured interviews in an hour or less. They can then convey detailed and reliable descriptions of the subject's responses and behavior to experts to complete the diagnosis. ${ }^{99}$ Thus, courts should use a rebuttable presumption of expertise.

In order to rebut the expertise presumption, the prosecution would have to show that the testifying officer either lacked the ability to distinguish mental illness or lacked sufficient opportunity to do so. The prosecution could attack ability by presenting academic and employment records devoid of training and experience concerning mental illness. Although everyday contact with unstable persons, by itself, would not prevent an officer from establishing lay status, any formal instruction about how to identify specific mental disorders would vitiate the rebuttal. The prosecution could attack opportunity by presenting testimony or records (such as an audio-videotape) concerning the specific interrogation. This showing would be difficult, if not impossible, because an expert officer can violate a suspect's rights even without extracting enough information to formulate an opinion (which would be inadmissible anyway). Therefore, the prosecution should have to prove that regardless of the interrogation's duration, the questions posed to the suspect were so few or benign that they did not elicit reactions useful for psychiatric diagnosis. Ability, then, would be the more effective line of attack. ${ }^{100}$

\footnotetext{
${ }^{97}$ See Beis, Mental Health and the Law at 243 (cited in note 11).

${ }^{88}$ Goodwin and Guze, Psychiatric Diagnosis at 294, 308-09 (cited in note 81).

${ }^{89}$ Scott Wetzler and Martin M. Katz, Contemporary Approaches to Psychological Assessment 92, 94 (Brunner/Mazel, 1989) (DIS and IMPS tests).

${ }^{100}$ The presumption of expertise might seem incongruous because it requires the government to attack the professional ability of one of its own officers and thus risk undermining the government's own image and other testimony of its witness. This harm can be minimized, if not eliminated, by determining expertise in camera. Furthermore, no disincentive
} 


\section{Police-obtained Sanity Evidence and Exceptions to the EXCLUSIONARY RULE}

Even if incriminating and testimonial, police-obtained evidence of sanity is admissible if it comes within an exception to the exclusionary rule. Both the waiver by offer of psychiatric evidence doctrine and the insanity rebuttal exception seek to give the prosecution a fair opportunity to rebut the defendant's insanity evidence. However, courts should apply neither exception to evidence obtained by police in violation of the privilege against self-incrimination because each goes too far in the prosecution's favor.

\section{A. Waiver Doctrine}

Unlike capital sentencing proceedings in which the prosecution has the burden of proving future dangerousness, a sanity determination generally requires a defendant to present expert testimony on his own behalf. The defendant's initiative then invites the prosecution not only to obtain and use psychiatric testimony in rebuttal, but also to argue that courts should include police-obtained evidence within the ambit of the waiver doctrine. Such a broad waiver doctrine is unjustified, however, because it would have retroactive effect and would give the state a disproportionate advantage over the defendant.

While the Supreme Court has not ruled on the constitutionality of a blanket waiver to objections against psychiatric or other evidence, Buchanan $v$ Kentucky ${ }^{101}$ offers some support for such a waiver doctrine. There, the Court held that a defendant who requests a mental examination and tries to establish a mental status defense at trial waives his constitutional objection to rebuttal evidence in the form of findings from the exam he requested. No $\mathrm{Mi}$ randa warnings were necessary as long as the defendant raised the issue at trial and the prosecution presented no inculpatory statements with the findings. ${ }^{102}$ Several courts have specifically indi-

to train officers "formally" would emerge because expert officers who observe required procedural safeguards can give valuable testimony.

101483 US 402 (1987).

${ }^{102}$ Id at 423-24. The Court recently expressed timid approval of this holding in Powell

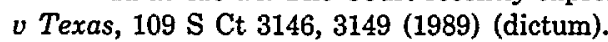

Buchanan and similar cases support the constitutionality of Rule 12.2 of the Federal Rules of Criminal Procedure and state analogues requiring defendants to advise the government of their intent to plead insanity and to submit to a court-ordered (i.e., compelled) government psychiatric examination. Rule 12.2(c) states that evidence from such a compelled exam is inadmissible on the issue of guilt and is admissible only on an issue of mental condition when the defendant first raises the issue. FRCrP 12.2(c). The ABA also endorses 
cated that the waiver applies retroactively to permit rebuttal testimony based on exams that preceded the defendant's decision to raise an insanity or other mental status defense. ${ }^{103}$ Theoretically, courts could extend this view to encompass sanity evidence obtained by police at the time of a suspect's arrest.

No court, however, appears to have extended the waiver doctrine to admit police-obtained evidence. If it were so extended, the defendant might have to rely on lay testimony to place his sanity in issue. ${ }^{104}$ And when the defendant retained the burden of proving his insanity, he would have to choose between his constitutional right to present exculpatory evidence and his constitutional privilege against self-incrimination.

One might infer that evidence from an exam requested by the defendant raises no Fifth Amendment objection because, by definition, the defendent voluntarily provides it. But, as the Buchanan dissent pointed out, an exam requested for the purpose of obtaining interim treatment may not yield voluntary evidence for the purpose of determining ultimate moral culpability for an alleged crime. ${ }^{105}$ The real rationale for permitting rebuttal with compelled sanity evidence seems to be a policy conclusion that expert testimony, however obtained, is the government's only effective response to the insanity defense. ${ }^{106}$

Courts have not universally accepted the waiver doctrine, and Buchanan is limited. In Byers, for example, Judge Scalia called the waiver theory "at best a fiction" where the relinquishment of Fifth Amendment privileges is not voluntary but the result of a court-

this view. ABA Criminal Justice Mental Health Standards § 7-3.4 at 88-95 (ABA, 1989). Aside from the absence of retroactive effect, one argument for why rules like 12.2(c) do not raise Fifth Amendment problems is the underlying notion, explored and rejected above, that evidence of sanity is not "incriminating" within the meaning of the.privilege against selfincrimination. See, for example, United States v Steinberg, 428 F Supp 77 (D Conn 1977).

103 See Granviel, 881 F2d at 190 (admitting results of pre-arrest examination performed when defendant was a juvenile); Madrid, 673 F2d at 1120-21 (admitting testimony based partly on competency exam); State $v$ Jones, 111 Wash 2d 239, 759 P2d 1183, 1187 (1988) (en banc); Hicks $v$ State, 256 Ga 715, 352 SE2d 762, 772 n 5 (1987).

104 An insanity defense relying solely on lay testimony is considerably less likely to succeed, Brown v Butler, $876 \mathrm{~F} 2 \mathrm{~d} 427,431$ (5th $\mathrm{Cir}$ 1989), and may even be insufficient to place the defendant's sanity in issue. See Case Note, Criminal Law-Defense of Insanity-Lay Witness Testimony Is Insufficient to Introduce the Issue of Defendant's Sanity, $62 \mathrm{U}$ Detroit L Rev 543 (1985).

${ }^{105} 483$ US at 426, 431-33 (Marshall dissenting).

${ }^{106}$ Buchanan may also rest on the testimonial waiver analogy. The state may argue that a defendant has no unlimited constitutional right to an insanity defense, and therefore the state may burden the use of that defense just as it may burden the defendant's right to testify in court. See White, $74 \mathrm{~J}$ Crim L \& Criminol at 954-63 (cited in note 10). 
decreed condition. ${ }^{107}$ The doctrine has not been applied when the defendant used only lay witnesses to place his sanity in issue. ${ }^{108}$ Nor have courts applied it to a mere plea of insanity. ${ }^{109}$ Finally, courts may easily limit Buchanan's holding to the admission of results of exams requested by the defendant when represented by counsel, at which point the "waiver" can more properly be deemed both voluntary and intelligent.

Even if courts can justify the waiver doctrine for psychiatric rebuttal evidence, however, they should not apply it to policeobtained evidence. First, the doctrine should not apply retroactively to either expert or lay sanity evidence obtained illegally. While several courts have admitted evidence from psychiatric exams preceding the defendant's insanity plea, or even his arrest, ${ }^{110}$ at least one court carefully indicated that its approval of the waiver doctrine depended on admitting only that privileged information obtained after notice of the insanity defense. ${ }^{111}$ Because courts ordinarily find waivers of the privilege against self-incrimination only when a party acts knowingly and voluntarily, ${ }^{112}$ it is difficult to see how a defendant could meet those conditions before he decides to plead insanity, much less before he obtains representation. ${ }^{113}$

Second, even if the waiver doctrine applies retroactively to mental examinations by expert psychiatrists, it should not extend to custodial interrogations by police. The Hinckley court distinguished police interrogations on the ground that they lack proce-

107740 F2d at 1113. See also State v Huff, 325 NC 1, 381 SE2d 635, 660 n 9 (1989), cert granted and judgment as to sentencing vacated and remanded on other grounds, $110 \mathrm{~S} \mathrm{Ct}$ 3266 (1990); White, $74 \mathrm{~J}$ Crim L \& Criminol at 948-49 (cited in note 10).

${ }_{108}$ Compare Brown v Butler, 876 F2d 427, 430 (5th Cir 1989) (witnesses were not experts), with Schneider v Lynaugh, 835 F2d 570, 576 (5th Cir 1988) (witnesses were experts).

100 Battie v Estelle, 655 F2d 692, 702 (5th Cir 1981); White, 74 J Crim L \& Criminol at $961 \mathrm{n} 85$ (cited in note 10).

110 See note 103.

11 Sturgis v Goldsmith, 796 F2d 1103, 1108 (9th Cir 1986).

112 See Culombe v Connecticut, 367 US 568, 602 (1961) (requiring waiver to be "free and unconstrained"). Although a truly insane defendant arguably could never make any intelligent waiver, his attorney could make strategic decisions on the defendant's behalf.

${ }^{123}$ Limiting the prosecution to evidence obtained after the defendant notifies it of his intent to plead insanity need not place the state at a disadvantage. Rules such as FRCrP 12.2 are specifically designed to give the prosecution sufficient advance notice to prepare to meet the insanity defense. If there is a risk that defense counsel might delay the decision whether to plead insanity so as to increase the time between the alleged crime and the state psychiatrist's diagnosis, and thereby to reduce the probative value of that diagnosis, a procedural rule could be added to expedite that decision. This delay also is unlikely because defense counsel will often request a psychiatric evaluation to secure treatment pending trial, and a prompt competency examination is also probable. 
dural safeguards that normally accompany compelled mental exams. ${ }^{114}$ Since psychiatrists and police officers both pressure suspects, often by subtle means, the circuit court's distinction seems weak.

But there is another, more persuasive reason to distinguish police interrogations. The main policy justification for the waiver by offer of psychiatric evidence doctrine is that, as in the analogous testimonial waiver context, adversarial proceedings must maintain a fair state-individual balance. This balance requires not only that the law protect the individual from overbearing state power, but also that the state have a fair opportunity to meet the suspect's defense. Courts have often mentioned the state's desperate need for expert psychiatric evidence as the only effective means to rebut defense experts. ${ }^{115}$ Yet, conceding that the state should have a fair opportunity to examine the defendant does not a fortiori require the admissibility of any and all sanity evidence, however obtained.

The use of illegally obtained police testimony to rebut an insanity defense would violate the proportionality test and would give the state an improper advantage. Just as an offer of lay sanity evidence does not waive objections to expert rebuttal evidence, an offer of expert sanity evidence should not waive objections to all government-obtained rebuttal evidence. The likelihood that a police officer not qualified as a psychiatric expert would contribute evidence that might unduly sway a jury leads to a disproportionate impact on the defendant. Moreover, the waiver theory developed in an era when most jurisdictions only required the defendant to produce some evidence to rebut the sanity presumption and make the prosecution carry the burden of proving sanity beyond a reasonable doubt. After Hinckley, numerous jurisdictions (including the federal courts) shifted the burden to the defendant to prove insanity by a preponderance of, or even clear and convincing, evidence. ${ }^{116}$ Subsequent waiver decisions have not considered this shift in the power balance, but it seems especially persuasive in supporting the argument that courts should not extend the waiver doctrine to police testimony.

114672 F2d at 133 in 116.

125 See, for example, United States $v$ Cohen, 530 F2d 43, 48 (5th Cir 1976); United States v Albright, 388 F2d 719, 724 (4th Cir 1968); State v Whitlow, 45 NJ 3, 210 A2d 763, 767 (1965).

${ }_{118}$ See, for example, Insanity Defense Reform Act of 1984, 18 USC § 17(b) (1988) (clear and convincing); Ill Rev Stat ch 38, § 6-2(e) (1989) (preponderance). Some jurisdictions also narrowed the test for insanity. See, for example, 18 USC § 17(a) (1988) (mental disease or defect must be "severe"). 
B. Insanity Rebuttal Exception

If the Fifth Amendment and its exclusionary rule are properly understood, there is no room for an insanity rebuttal exception. Nevertheless, several courts and commentators have endorsed such an exception either by combining the impeachment exception with a testimony-by-proxy theory, or by invoking the sheer practical need for rebuttal testimony to offset the difficulty of disproving insanity. As the Hinckley court held, however, these justifications are flawed.

The impeachment exception is not available where, as posited in this Comment, the defendant does not testify. But at least one court has endorsed a testimony-by-proxy theory to support an insanity rebuttal exception to the exclusionary rule. In People $v$ Finkey, ${ }^{117}$ an Illinois appellate court held that a statement obtained by police in violation of Miranda was admissible to rebut expert testimony that the defendant suffered from pathological intoxication. Although Finkey did not testify at trial, the court believed that the impeachment rationale applied because the trial judge admitted Finkey's statements to police only in rebuttal and after he instructed the jury to consider them only as they related to Finkey's state of mind. "Just as a defendant cannot be allowed to directly perjure himself and then hide behind the fifth amendment," the court concluded, "he cannot be allowed to prima facie establish an insanity defense by his representations to a psychiatrist without affording the State an opportunity to challenge the veracity of those statements."118 This holding implicitly approved the testimony-by-proxy theory rejected in Hinckley.

Arguments favoring an insanity rebuttal exception stem from deep distrust of the insanity defense and the prosecution's difficulty in rebutting it. Thus, the exception could help defeat fraudulent insanity defenses by equalizing the available proof on the sanity issue and by challenging dubious testimony by proxy. Furthermore, police lack the same incentive to violate suspects' constitutional rights after obtaining evidence of guilt. Finally, the trier of fact arguably needs all available evidence to make an informed decision about the defendant's sanity. ${ }^{119}$

117105 Ill App 3d 230, 434 NE2d 18 (1982).

118434 NE2d at 20.

110 These arguments are advanced in Comment, The Use of Illegally Obtained Evidence to Rebut the Insanity Defense: A New Exception to the Exclusionary Rule?, $74 \mathrm{~J}$ Crim L \& Criminol 391, 417-25 (1983). See also Daley and Fryklund, 21 Valparaiso U L Rev 
Despite these arguments, an insanity rebuttal exception to the Fifth Amendment exclusionary rule is unwarranted. ${ }^{120}$ First, as in the "waiver by offer of psychiatric evidence" context, shifting the burden of proof on the sanity issue to the defendant undermines the state's argument that it needs illegally obtained evidence to rebut the insanity defense. The prosecution also should be able to obtain sanity evidence from other sources, such as booking officers and additional lay witnesses. ${ }^{121}$

More importantly, however, the testimony-by-proxy theory is fatally flawed. Testimony by a defense psychiatrist does not equate precisely with the defendant's testimony because the psychiatrist's evaluation filters the defendant's story. The credibility of that story is therefore more properly tested by cross-examining the psychiatrist who testifies in court. ${ }^{122}$

The testimony-by-proxy theory is analogous to the perjury-byproxy theory rejected by the Supreme Court in James $v$ Illinois. ${ }^{123}$ In James, the Court decided not to enlarge the Fourth Amendment exclusionary rule's impeachment exception to permit the prosecution to use illegally obtained evidence to impeach the testimony of defense witnesses other than the defendant. The Illinois Supreme Court had expressly adopted a perjury-by-proxy theory for expanding the impeachment exception to admit any part of a suppressed statement short of a confession. But five Justices rejected the perjury-by-proxy theory and refused to permit the impeachment exception where the defendant did not testify.

The Court's decision in James probably means that to the extent that the insanity rebuttal exception to the Fifth Amendment exclusionary rule would rely on a perjury-by-proxy or testimonyby-proxy theory, the Court would reject it. With respect to a trial's guilt phase, the perjury-by-proxy theory says that a defendant

at 500 (cited in note 11) (arguing for the admissibility of a defendant's post-arrest behavior to rebut his testimony through psychiatric expert proxies).

${ }^{120}$ Some theorists would argue that a debate about the viability of the testimony-byproxy theory completely misses the mark because, contrary to Supreme Court decisions like Harris, truth-seeking and deterrence of police misconduct are not the only rationales underlying the Fifth Amendment exclusionary rule. Rather, the Fifth Amendment guarantees defendants an absolute procedural right of exclusion, and no exceptions at all are defensible. See, for example, Loewy, 87 Mich L Rev at 908 (cited in note 15); Bostjan M. Zupancic, The Privilege Against Self-Incrimination, 1981 Ariz St L J 1. On this view, the Harris impeachment exception has no place at all in insanity rebuttal analysis. Notwithstanding these criticisms, the Court continues to balance the privilege against self-incrimination against other systemic interests. See, for example, James v Illinois, 110 S Ct 648 (1990).

${ }^{121}$ Daley and Fryklund, 21 Valparaiso U I Rev at 524 (cited in note 11); Note, 83 Harv

L Rev at 670-71 (cited in note 61).

${ }_{122}$ White, $74 \mathrm{~J}$ Crim L \& Criminol at 985 (cited in note 10).

$123110 \mathrm{~S}$ Ct 648. 
should not be able to avoid impeachment with unconstitutionally obtained evidence by putting a friendly witness on the stand to testify erroneously in his favor. The James majority found this theory unpersuasive because the threat of perjury prosecution deters a witness more than it deters a defendant already facing conviction for the underlying offense. ${ }^{124}$ More importantly, perhaps, the majority also feared that "expanding the impeachment exception to encompass the testimony of all defense witnesses likely would chill some defendants from presenting their best defense-and sometimes any defense at all-through the testimony of others." ${ }^{25}$ Finally, the deterrent effect on police misconduct would be weakened. ${ }^{126}$

Just as the James majority rejected the perjury-by-proxy theory for a trial's guilt phase, courts should reject the testimony-byproxy theory for the sanity phase. The chilling effect would be particularly strong in the sanity context because the defendant might risk losing his only defense to avoid execution. The disadvantage to the insanity defendant would be especially harsh because, unlike James, he is in a weaker position to offer patently false information through a psychiatrist. The psychiatrist need not lie to present favorable testimony, and his view of the defendant's sanity is less likely to be intentionally erroneous than an actus reus alibi reported by a friendly defense witness. ${ }^{127}$

The James majority also disagreed that excluding illegally obtained evidence from the prosecution's case-in-chief would provide sufficient deterrence. When police officers have gathered ample proof of a suspect's actus reus from lay witnesses and evidence at the crime scene, they will have little to lose and much to gain by illegally interrogating the suspect. In James, the detectives who unlawfully detained James already knew of several eyewitnesses to the crime; similarly, in Hinckley, the FBI agents surely were aware that numerous bystanders had witnessed the assassination attempt. Thus, although the deterrence rationale may not be fundamental to the Fifth Amendment's per se exclusionary rule, proper regard for deterrence weighs heavily against an insanity rebuttal exception.

${ }^{124}$ Id at 658. Of course, an expert psychiatrist testifying for the defense and offering opinion testimony about the defendant's mental status runs virtually no risk of perjury.

126 Id at 659.

128 Id.

${ }^{127}$ This vitiates Justice Kennedy's complaint that the James majority ignored the "almost certain knowledge that the testimony immunized from rebuttal is false." Id at 665 (Kennedy dissenting). 


\section{CoNCLUSION}

In order properly to apply the Fifth Amendment exclusionary rule to police-obtained evidence of sanity, courts should reject (at least in part) four major theories heretofore used to justify rebutting the insanity defense with evidence obtained in violation of $\mathrm{Mi}$ randa: non-incriminating; non-testimonial; waiver; and an insanity rebuttal exception.

First, courts should reject the argument that evidence of sanity is not incriminating. Evidence that exposes a defendant to qualitatively worse imprisonment (or even death) than hospitalization should be deemed incriminating under Smith.

Second, depending on the expertise with which a police interrogator probes the defendant's mind for sanity evidence, courts should treat certain evidentiary products of that interrogation as testimonial. Regardless of the officer's expertise, they should exclude his opinions. A lay officer unavoidably will incorporate the defendant's statements into his opinion as a witness, contrary to the prohibition on using compelled, incriminating, testimonial evidence. An expert officer, like a psychiatrist, theoretically might be able to reach a substandard expert opinion based only on demeanor observations. But since courts should view compelled physiological reactions as testimonial, like statement contents, they ought to exclude such an opinion. And in the expert officer's case, even the underlying demeanor observations should be excluded.

Some police officers will lack psychiatric expertise, however, and courts should therefore permit their testimony concerning the discrete observations underlying their tacit opinion. This testimony may have considerably less weight before the jury, but may nonetheless corroborate the prosecution's expert psychiatric testimony. Courts therefore should answer the constitutional admissibility question by determining the relative expertise of the law enforcement officer whose testimony the prosecution seeks to admit.

Finally, where police-obtained evidence of sanity is at once compelled, incriminating, and testimonial, the courts should permit no exceptions to the Fifth Amendment exclusionary rule for insanity rebuttal purposes. Courts should refrain from extending the waiver by offer of psychiatric evidence doctrine to police rebuttal testimony because the state-individual balance would become skewed in the state's favor. This power transfer would be particularly egregious in those jurisdictions where the defendant now has the burden of proof on insanity. 
Similar policy concerns should discourage courts from adopting a narrow insanity rebuttal exception to the exclusionary rule. The testimony-by-proxy theory in the sanity context is as flawed as the perjury-by-proxy theory rejected in James. And where the government already can compel a psychiatric examination for rebuttal purposes, there is insufficient need and justification for broadening the impeachment exception to admit police-obtained sanity evidence when the defendant declines to testify. Courts should not interpret the Fifth Amendment as allowing the government to overcome the highly controversial insanity defense by introducing procedurally tainted police testimony. 
